\title{
Interaction of Higher School and Employers on Training of Management Personnel in Digital Society (According to Materials of Mass Media and Social Media)
}

\author{
S.A. Zakharova ${ }^{1}$ and E.N. Yudina ${ }^{2}$ \\ ${ }^{1}$ Russian Academy of National Economy and Public Service under the President of the Russian \\ Federation, Moscow, Russian Federation \\ ${ }^{2}$ Moscow Pedagogical State University, Moscow, Russian Federation
}

\section{Abstract}

This article is devoted to the requirements that digital society proposes to educational organizations and employers. Educational organizations should improve the specialists' and employers' training quality as well as their participation in the evaluation of educational programs. Ensuring the quality of education is a task of all actors in the education system such as educational organizations, students, their parents, and

Corresponding Author:

S.A. Zakharova

Published: 21 January 2021

Publishing services provided by Knowledge E

(c) S.A. Zakharova and E.N. Yudina. This article is distributed under the terms of the Commons Attribution License, which permits unrestricted use and redistribution provided that the original author and source are credited.

Selection and Peer-review under the responsibility of the XXIII International Conference Conference Committee. employers. The authors carried out a study to determine employers' opinion on the question referring to training quality in Moscow higher schools. For this purpose, leading Moscow universities were selected that have the right to form and approve their own educational standards. The study has fixed the positive nature of the most publications in mass-media in relation to the largest Moscow universities. There is positive coverage of university graduates' employment and adaptation problems. The information reasons were universities activities that contribute to the improvement of the graduates' competence level. The study has revealed that the problems of evaluation and quality assurance of education are relevant not only for educational organizations, but also for employers. The research has determined that the requirements of the digital society development are such that educational organizations as producers and suppliers of labour should be more result-oriented, and employers should be directly involved in the formation and evaluation of the quality of educational programs.

Keywords: digital society, educational organizations, quality of education, employers, social and traditional media. Media messages, specialists, labour market, quality of education, Moscow universities.

\section{Introduction}

Digital society has a dynamic and innovative nature. First of all, it is characterized by orientation to new knowledge, electronic form of text and video-audio information presentation and active introduction of the Internet environment into the business and 
An important consequence of the advent of digital society is a special culture formation in which the digital symbol has become an important value as an indicator of many phenomena and processes. It can be expressed in the form of a rating, a score, a "likes," a currency exchange rate, etc. Digital society forms a digital culture, introduces social life into a network virtual space, where many spheres of activity (including education) receive a sign expression, a symbolic form in the form of charts and figures, graphic images. Modern social institutions are able to develop simultaneously in two spaces: in network space and physical reality, helping each other [1]

Time and digital society put their demands on modern education. Teachers need to be able to use interactive teaching techniques using the Internet. Students should also be able to acquire, update and apply their own knowledge through the Internet, to show initiative, independence and responsibility, to master the achievements of domestic and world culture, to be able to prove their competitiveness in the process of activity. All this determines the requirements for the quality of education today.

Ensuring the modern education quality is a task which all actors of the education system and interested parties - educational organizations, students and their parents, employers, members of the public, the State are interested in. The most important procedure in the education system that confirms the quality of educational programs is accreditation. Accredited is an educational program whose quality can be trusted. The accreditation procedure is a comprehensive process involving both government monitoring organizations and independent education quality assessment centers, including employers. Representatives of the professional community - employers as the main consumers of young professionals - graduates of educational organizations - and, dictating requirements to the level of their competence, are an integral participant in the assessment of the quality of education.

The form of educational activities recognition by the professional community is vocational and public accreditation - a system of external monitoring and evaluation of training of personnel aimed at improving educational programs and ensuring the specialists' training quality in accordance with the requirements of the labour market. Educational organizations train specialists, and representatives of the labour market trust the quality of such training, accepting employees with a diploma of a specific educational organization, on the one hand, and participating in accreditation procedures of educational programs, on the other hand [2]

Traditional and social media play a huge role in the formation and maintenance of trust in the educational organization [3]. In social media, actors - users of the network - actively use this space to guide what professions higher education offers 
today, information about potential employers and employees is easily disseminated, for example, when any recruitment agencies search for employees by person-to-person transferring information in social media, or HR managers constantly monitor information on future employees for their organization in networks as well. Now Web-sites with many feedbacks are very popular, thus, the employer on social networks can easily see a picture on a particular university, and when hiring to draw a conclusion from which university helshe will hire the employee.

\section{Methodology and Methods}

Qualitative characteristics of HR training of the established digital society were considered in L.A. Vasilenko's works [4, 5]. Practical issues and sociological research referring to the university graduates' demand on a labor market are considered in the works of E.N. Yudina and V.N. Trenev [2, 9]. The public administration implementation specifics in digital society are presented in the work "Public value management and the digital state - signifying trends in the development of public administration" [6]; the research referring to attitudes to education through crowdsourced technologies is presented in the work by Zakharova S. A. "Crowdsourcing Technologies for Civil Activity in Russia (through the project "Active Citizen") [11]. The specifics of interaction between citizens and subjects of the educational process in social media are reflected in the work "Social Networks in the Mirror of Sociology" [9].

The interaction between higher education and employers, according to the authors, should be based on a system of trust, as each of these entities performs its own status role in the system:

- Labour market representatives determine the quality of training of specialists by accepting graduates of a specific educational organization and participating in accreditation procedures of educational programs,

- The Ministry of Education of the Russian Federation establishes qualification requirements in the State Educational Standards and ensures control on behalf of the State;

- Educational organizations develop educational programs in accordance with the requirements formulated by employers and ensure their qualitative implementation;

- Traditional media and social media ensure publicity of all processes. 
The authors of the article conducted a study to identify the attitude of Moscow universities and large employers to the problems of quality of education.

Within the framework of this research it was decided to apply the capabilities Online PR and Social Media Monitoring System in real time - Medialogy [4]. Daily the system is filled with content from 52,000 sources of media and 900,000,000 accounts in social networks, aggregating everything and offering various options of their filtration and aggregation in forms of account with the indication of references to sources.

For this purpose, leading Moscow universities were selected, having the right to form and approve their own educational standards - Moscow State University named after M.V. Lomonosov, MGIMO University, Financial University under the Government of the Russian Federation, RANEPA under the President of the Russian Federation, RUDN University.

As employers were considered leading corporations - Rosatom, Rosnano, Rostech, Rosgosstrakh, Roscosmos, Vnesheconombank, Sberbank, VTB, Gazprom, Rosneft.

\section{Results and Discussion}

During the annual period ( January 2018 - January 2019), more than 22 thousand reports were published in the media, covering more than 9000 events on various aspects of the quality of education, mentoring and employment of young professionals, in which leading corporations are mentioned. The average coverage of the media that published the reports is 4.5 million - between 0.2 million and 41.6. Mass media level is federal, regional, foreign one. The rating of messages is based on the visibility of the event (Visibility is a cumulative parameter takes into account the 'advertising equivalent' of the publication depending on the number of the strip, the volume of the message, as well as the circulation, attendance of the source by the audience). This indicator of 'visibility' together with two more - "citation index" and "positive/negative" make up the Media Index. In this study, the Media Index shows the positive nature of most publications. The top 10 events involving employers represented by corporations covered in the media in the context of the quality of education and employment problems of university graduates are presented in Table 1.

The publications analysis has revealed that the words 'contest,' student, 'leader,' mentor, 'young,' winner, 'specialist,' university, 'school,' were used most often in reports.

Thus, problems of employment and adaptation of young professionals, as well as activities contributing to the level of graduates' competence, such as mentoring, training 
TABLE 1: Top 10 events covered in the media (in the context of the quality of education and employment problems of university graduates)

\begin{tabular}{|c|c|}
\hline $\mathbf{N}^{\circ}$ & Event \\
\hline 1. & $\begin{array}{l}\text { Sberbank calculates level of } \\
\text { salaries of young specialists }\end{array}$ \\
\hline 2. & Operate and participate \\
\hline 3. & $\begin{array}{l}\text { Participants of "Leaders of } \\
\text { Russia" will be able to receive } \\
\text { training in the largest } \\
\text { companies }\end{array}$ \\
\hline 4. & Educated and not needed \\
\hline 5. & $\begin{array}{l}\text { Winners of the World Hi-Tech } \\
2018 \text { championship WorldSkills } \\
\text { announced in Yekaterinburg }\end{array}$ \\
\hline 6. & $\begin{array}{l}\text { Finalists of the Olympic Games } \\
\text { "I am a professional" will learn } \\
\text { about new technologies }\end{array}$ \\
\hline 7. & The heard mentors of youth \\
\hline 8. & $\begin{array}{l}\text { ROSNANO selected the first } \\
\text { participants for Business Debut } \\
\text { 2018-2019 }\end{array}$ \\
\hline 9. & $\begin{array}{l}\text { The stage for prodigies: why } \\
\text { "Sirius" status of "scientific } \\
\text { valley" }\end{array}$ \\
\hline 10. & $\begin{array}{l}\text { Rostrud will launch "Russian } \\
\text { Linkedln" }\end{array}$ \\
\hline
\end{tabular}

\begin{tabular}{|c|c|c|c|}
\hline $\begin{array}{c}\text { Event } \\
\text { visibility }\end{array}$ & $\begin{array}{c}\text { Number of } \\
\text { Messages }\end{array}$ & $\begin{array}{c}\text { Audience } \\
\text { Reach }\end{array}$ & $\begin{array}{c}\text { Media } \\
\text { Index }\end{array}$ \\
\hline 57.38 & 297 & $4.6 \mathrm{mln}$ & 3731.20 \\
\hline 56,04 & 507 & $8,2 \mathrm{mln}$ & 2424.10 \\
\hline 19.64 & 66 & $14.0 \mathrm{mln}$ & 2734 \\
\hline 11,23 & 8 & $1,0 \mathrm{mln}$ & 204 \\
\hline 9,43 & 72 & $8.4 \mathrm{mln}$ & 924 \\
\hline 8.93 & 74 & $12,3 \mathrm{mln}$ & 810.70 \\
\hline 8.88 & 8 & $0.8 \mathrm{M} / \mathrm{H}$ & -9 \\
\hline 8.61 & 20 & $0.2 \mathrm{mln}$ & 469 \\
\hline 7.94 & 40 & $3.9 \mathrm{mln}$ & 218 \\
\hline & & & \\
\hline & & & \\
\hline
\end{tabular}

programs implemented by corporations, various competitions of professional skills implemented with the participation of corporations, are a significant newsbreak.

For comparison, we consider newsbreaks in the context of mention of leading universities, quality of education and accreditation (Table 2).

During the same annual period, more than 26,000 reports were published in the media, covering more than 10,000 events devoted to various aspects of the quality of education, which mention leading Moscow universities. The average coverage of the media that published the reports is 7.5 million. Mass media levels are federal, regional, foreign. The rating of messages is based on the visibility of the event Media Index testifies to the positive nature of most publications (average index -747 ).

Analysis of the meaning of publications within the framework of leading universities in Moscow has revealed that the words 'university,' accreditation, 'university,' education, 'rating' were most often used in those reports.

It can be argued that universities in a digital society are increasingly result-oriented, and employers should be more involved in shaping and evaluating the training quality. 
TABLE 2: Top 10 events covered in the media (with the participation of leading universities in the context of quality of education and accreditation)

\begin{tabular}{|c|c|c|c|c|c|}
\hline $\mathbf{N}^{\circ}$ & Event & $\begin{array}{l}\text { Event } \\
\text { visibility }\end{array}$ & $\begin{array}{l}\text { Number of } \\
\text { Messages }\end{array}$ & $\begin{array}{l}\text { Audience } \\
\text { Reach }\end{array}$ & Media Index \\
\hline 1. & $\begin{array}{l}\text { Forbes has compiled a rating } \\
\text { of Russian universities }\end{array}$ & 80.73 & 392 & $37,1 \mathrm{mln}$ & 5198.10 \\
\hline 2. & $\begin{array}{l}\text { One of the leading universities } \\
\text { in Russia lost accreditation. } \\
\text { What occurs? }\end{array}$ & 22.72 & 94 & $11.1 \mathrm{mln}$ & 511 \\
\hline 3. & $\begin{array}{l}\text { Rectors criticized the system of } \\
\text { assessment of the quality of } \\
\text { universities }\end{array}$ & 22.19 & 104 & $16.5 \mathrm{mln}$ & 587 \\
\hline 4. & $\begin{array}{l}\text { Moscow State University } \\
\text { entered the top } 100 \text { rating of } \\
\text { universities ARWU- } 2018\end{array}$ & 18.39 & 53 & $15.6 \mathrm{mln}$ & 1313 \\
\hline 5. & The best of the higher... & 16.30 & 64 & $4.4 \mathrm{mln}$ & 2170.10 \\
\hline 6. & $\begin{array}{l}\text { The Head of the Ministry of } \\
\text { Education and Science noted } \\
\text { the increase in recognition of } \\
\text { the Russian challenge abroad }\end{array}$ & 12.74 & 43 & $27.4 \mathrm{mln}$ & 562 \\
\hline 7. & We are open for the world & 12.44 & 24 & $1.3 \mathrm{mln}$ & 253 \\
\hline 8. & $\begin{array}{l}\text { The Center for the World } \\
\text { Rating of Universities } \\
\text { published the top } 1000 \\
\text { universities of the world }\end{array}$ & 12.13 & 37 & $17.2 \mathrm{mln}$ & 677 \\
\hline 9. & Secret diplomacy & 11.74 & 11 & $3.7 \mathrm{mln}$ & 1101 \\
\hline 10. & In consequence, who? & 11.42 & 8 & $1.8 \mathrm{mln}$ & 270 \\
\hline
\end{tabular}

Then such cooperation will establish a closer connection between universities and employers, because today the problem of employment after graduation is relevant.

\section{Conclusions}

The study has determined that the problems of assessing and ensuring the education quality in digital society are relevant not only for educational organizations, but also for employers. The requirement of the modern society development is that universities as producers and suppliers of labour service should be more result-oriented, and employers should be directly involved in the formation and evaluation of educational programs.

It should be noted that the increase in the employer's and students' requirements is the higher education final product.

The university graduates' competences should be most consistent with educational standards. It should be strengthening state control over the quality of education, introducing a system of independent control the students' knowledge and the creation of 
public systems of independent control of the education quality with the involvement of employers.

\section{Acknowledgments}

The reported study was funded by RFBR, project number 20-011-00694 «Public Administration as Configuring of Relational Networks in the Public Space of a Digital Society»

\section{References}

[1] Medialogia. (2020). Online PR and Social Media Monitoring System. Retrieved January 20, 2018 from http://www.mlg.ru

[2] Pobedonostseva, M. G. (2016). Requirements to Education in Modern Society Development. In: International scientific online-conference "Actual problems of ITtraining methods in modern school". Moscow: MPSU, pp. 16-17.

[3] Tapscott, D. (1999). The Digital Economy: Promise \& Peril in the Age of Networked Intelligence. New York: McGraw-Hill Ryerson, p. 432.

[4] Vasilenko, L. A. (2004). Forestalling Education as a Way of the Mankind's Survival. Bezopasnost Evrazii, vol. 3, issue 17, pp. 491-505.

[5] Vasilenko, L. A. (2007). System and processes of innovative training of civil servants. Education and Society, vol. 3, pp. 51-59.

[6] Vasilenko, L. A. (2018). Public value management and the digital state - significant trends in the development of public administration. Public administration and development of Russia: challenges and opportunities. Collection of articles of the international conference session, vol. 1. In G. Y. Ivleva, (Ed.). Publishing house "Scientific Library", pp. 149-155.

[7] Yudina, E. N. and Trenyev, V. N. (2017). Students of Different Higher Schools at Labour Market. Science and School, vol. 6, pp. 53-58.

[8] Yudina, E. N. and Zakharova, S. A. (2017). Social Networks in the Mirror of Sociology. Moscow: Publishing House Sputnic, p. 164.

[9] Yudina, E. N. and Zakharova, S. A. (2015). Social Networks through Different Scientific Paradigms. Labour and social relations, vol. 3, pp. 23-34.

[10] Zakharova, S. A. (2016). Crowdsourcing technologies for civil activity in Russia (through the Project "Active Citizen"). University Vestnik (State University of Management), vol. 5, pp. 263-268. 